Magdalena Ochońska, Mediacja rodzinna w poradniach przyparafialnych szansq dla maṫ̇enstw w kryzysie?, [w:] Cztowiek w relacji do... Rozważania o cztowieku jako istocie relacyjnej, red. Grzegorz Wąchol, Kraków 2020, s. 103-116.

DOI: http://dx.doi.org./10.15633/9788374388740.07

MGR MAGDALENA OCHOŃSKA

\title{
Mediacja rodzinna w poradniach przyparafialnych szansą dla małżeństw w kryzysie?
}

Tematem konferencji, która odbyła się na Uniwersytecie Papieskim Jana Pawła II w Krakowie 30 maja 2019 roku, organizatorzy uczynili zagadnienie relacji - do Boga, drugiego człowieka i samego siebie, łącząc tym samym kwestie filozoficzne, teologiczne i społeczne. Wszystkie te relacje opierają się na komunikacji zachodzącej między jedną a drugą stroną. Bez prawidłowej komunikacji nie możemy mówić o rozwoju więzi, ale także o rozwoju osobowym każdego z nas. Gdy więc nie zaznamy tego rozwoju w relacji, wtedy mogą się rodzić trudności i problemy, w tym także konflikty w relacjach małżeńskich.

Węzeł małżeński jako uświęcony i podniesiony do rangi sakramentu ma niebagatelne znaczenie w funkcjonowaniu pozostałych relacji. Wszak dzięki prawidłowym relacjom między małżonkami budowane mogą być umiejętności utrzymywania poprawnych relacji z Panem Bogiem, innymi ludźmi, jak również z samym sobą, dlatego tak ważne jest, aby Kościół - nie tylko jako wspólnota wiernych, ale także instytucja - stał na straży rozwoju poprawnych i pełnych miłości relacji oraz wspierał w tym rodziny. 
Aby wypełnić tę misję, Kościół prowadzi poradnie życia rodzinnego oraz poradnie specjalistyczne, w których posługują zarówno duchowni, jak i specjaliści z różnych dziedzin mający za zadanie wspierać rodziny w wypełnianiu ich funkcji. Jednym $z$ tych specjalistów jest mediator. Mimo jego powszechnej obecności mediacja realizowana przy parafii przysparza pewnych pytań natury etycznej, praktycznej i organizacyjnej. I te właśnie pytania zostaną postawione w tym artykule. Szukanie odpowiedzi wymaga pogłębionej refleksji teoretycznej, ale przede wszystkim praktycznej. Celem artykułu jest wskazanie tych trudności i zachęcenie czytelnika do zainteresowania się tą problematyką.

\section{Mediacja rodzinna - podstawy teoretyczne}

Na samym wstępie należy przedstawić, czym ta mediacja rodzinna $\mathrm{w}$ istocie jest. Mediacja to dobrowolny, poufny, wyspecjalizowany, nieformalny sposób rozwiązywania sporów prowadzony przez mediatora (bądź dwóch mediatorów, najczęściej przeciwnej płci) zaakceptowanego przez obie strony, którego zadaniem jest uporządkowywanie i udrażnianie komunikacji. Sam mediator pozostaje bezstronny i neutralny wobec przedmiotu sporu, a dzięki jego udziałowi strony wypracowują satysfakcjonujące je rozwiązanie $^{1}$. W tej definicji można znaleźć najważniejsze zasady, które przyświecają mediacji, a wśród nich - w przypadku tego artykułu - najistotniejsze to zasady bezstronności mediatora i jego neutralności wobec przedmiotu sporu. O tym, dlaczego akurat te zasady są tu podkreślone, będzie mowa w dalszej części tego opracowania.

1 Por. A. Kalisz, A. Zienkiewicz, Mediacja sqdowa i pozasq̨owa. Zarys wyktadu, Warszawa 2014, s. 42-62. 
Mediacja rodzinna mieści się w kategorii mediacji cywilnych, które są zaraz obok mediacji karnych i mediacji w sprawach nieletnich podstawową gałęzią mediacji. Mediacje te różnią się od siebie regulacjami prawnymi dotyczącymi m.in. wykształcenia mediatora, kosztów mediacji i innych. Mediacje rodzinne znajdują się w dziale mediacji cywilnych obok takich spraw jak mediacje gospodarcze, prawa pracy, rówieśnicze czy akademickie. Same mediacje rodzinne to nie tylko sprawy między małżonkami, ale także między dziećmi, rodzicami czy innymi krewnymi. Rzeczywiście jednak najczęściej w praktyce i literaturze, mówiąc o mediacjach rodzinnych, mówi się właśnie o pośrednictwie między małżonkami. Także i tutaj skoncentrujemy się na tym rodzaju mediacji. Najczęstszymi sprawami zgłaszanymi przez stronę są warunki rozwodu oraz opieka nad dziećmi, podział majątku, wysokość alimentów² itd. Mediacja rodzinna może być rozpoczęta na dwa podstawowe sposoby: ze skierowania sądu - czyli sąd podczas rozprawy proponuje stronom mediację i mediatora ( $z$ listy mediatorów sądowych) - lub z własnej inicjatywy stron - jest to mediacja umowna, chodzi więc o sprawy, w których nie ma rozpoczętej procedury sądowej. Zarówno w przypadku sądowych, jak i umownych mediacji nie ma mowy o naruszeniu zasady dobrowolności, ponieważ w obu tych mediacjach strony w każdej chwili moga przerwać ten proces. Gdy strony trafią do mediatora (lub mediatorów), zaczyna on spotkanie od tzw. monologu mediatora, w którym opisuje przebieg mediacji, sprawy organizacyjne, ustala zasady spotkań, czas trwania, sposób płatności itd. Podczas tego monologu mediatora strony mogą przekonać się o jego profesjonalizmie i uporządkowanym sposobie myślenia. Dobrze przeprowadzony mono$\log$ to dobry wstęp do dalszej części działania. Następnie każda

2 Por. A. Cybulko, Mediacja w sprawach rodzinnych, w: Mediacje. Teoria i praktyka, red. E. Gmurzyńska, R. Morek, Warszawa 2014, s. 299-318. 
ze stron ma czas na przedstawienie swojego punktu widzenia na przedmiot sporu i ustalenie kwestii do rozwiązania, by potem z mediatorem szukać wyjścia $z$ sytuacji przez prawidłowe dojście do swoich potrzeb. Gdy takie się znajdzie, konstruowane i spisane jest porozumienie. Tak w dużym skrócie przedstawia się schemat mediacji.

Wspomniane wcześniej warunki rozstania to tzw. mediacje ukierunkowane prawnie (legally oriented mediation) - czyli mediacje skupiające się na płaszczyźnie prawnej i określające przedmioty sporu, które sąd musi podnieść w sprawach sądowych. Ale pozostają także dwa inne rodzaje mediacji, które wyróżnił amerykański specjalista do spraw mediacji rodzinnej John Haynes, mianowicie "mediacje ukierunkowane terapeutycznie" (therapy-oriented mediation) oraz „mediacje zrównoważone” (mediation with a balanced orientation $)^{3}$. Podział ten dla zrozumienia trudności podejmowanego zagadnienia jest bardzo trafny, ponieważ analiza zasadności i skuteczności prowadzenia mediacji w poradniach przyparafialnych zależy także od tego, z jakim typem mediacji rodzinnych mamy do czynienia. Mediacje ukierunkowane terapeutycznie to spotkania, które za główny cel obierają sobie naprawę relacji czy odbudowę poprawnej komunikacji. Mediacje zrównoważone, jak sama nazwa wskazuje, mają równoważyć podjęte cele zarówno prawne, jak i terapeutyczne w spotkaniach ze stronami.

Przedstawione powyżej podstawowe i dość ogólne informacje na temat mediacji mogą wskazywać na wartości, jakie możemy w niej znaleźć, takie jak: równość, poczucie bezpieczeństwa, wzajemny szacunek i dobra wola. Te wszystkie wartości, które mediacja promuje także bezpośrednio, można znaleźć również w nauczaniu

3 Por. E. Sobczak, Mediacja rodzinna jako forma polubownego rozwiazywania sporu, w: Rodzina. Podstawy prawno-teologiczne, red. J. Zimny, Stalowa Wola 2015, s. 663-672. 
Kościoła katolickiego, a dokładniej w realizowanym w jego obrębie duszpasterstwie rodzin.

\section{Duszpasterstwo rodzin - cele i sposoby działania}

Duszpasterstwo rodzin to forma pracy i ewangelizacji rodziny, małżonków czy dzieci, tak, aby szła ona przez życie niesiona słowem Bożym i stawała się wzorem do naśladowania i wsparciem dla bliźnich. Elementem tego duszpasterstwa jest także dowartościowanie miłości i miłosierdzia małżonków i rodzin. W wielu różnych problemach, z jakimi borykają się małżonkowie, można zapomnieć o miłosierdziu jako wartości i sposobie życia w małżeństwie. Wskazuje na to ks. Wiesław Przygoda: „dużym problemem wielu współczesnych małżonków jest przemiana pierwotnej miłości ofiarnej w postawę zimnego wyrachowania, które nie jest zdolne zdobyć się na wzniosłą postawę przebaczenia czy przeproszenia, a co za tym idzie, na postawę małżeńskiego miłosierdzia"4. Ważne jest więc, by w realizowanym duszpasterstwie rodzin promować takie wartości, które wiążą się z przebaczaniem i proszeniem o przebaczenie. Jak pisze ks. dr Mirosław Brzeziński, Kościół katolicki w swojej działalności „czuje się odpowiedzialny za te wspólnoty i dlatego czuje też konieczność dogłębnego zaangażowania duszpasterskiego w ochronę, pomoc i promocję tych instytucji”, jakimi są małżeństwo i rodzina 5 .

4 W. Przygoda, Dowartościowanie mitości i mitosierdzia w duszpasterstwie rodzin, w: Towarzyszyć matżenstwu i rodzinie. Inspiracje adhortacji apostolskiej „Amoris laetitia” dla duszpasterstwa rodzin, red. J. Goleń, Lublin 2017, s. 152.

5 M. Brzeziński, Duszpasterskie wsparcie rodziny, w: Wsparcie rodziny. Zatożenia i praktyka w ujęciu interdyscyplinarnym, red. A. Regulska, A. J. Najda, Warszawa 2017, s. 77. 
Można więc zaryzykować stwierdzenie, że mediacja rodzinna $\mathrm{w}$ pełni wpisuje się $\mathrm{w}$ promocję takich postaw, a podstawowymi miejscami do ich upowszechniania są Kościół domowy i parafia.

W Konstytucji duszpasterskiej o świecie współczesnym Gaudium et spes czytamy, że grupy czy poszczególni małżonkowie mają za zadanie także wspierać narzeczonych i małżonków w wypełnianiu ich powołania, wspierając ich i towarzysząc im ${ }^{6}$. Widać więc wyraźnie, jakie zadanie stawia przed wiernymi Sobór Watykański II, ale nie on jedyny. W ostatnich latach papież Franciszek powtórzył to, pisząc do polskich biskupów:

Niech wspólnoty kościelne będą miejscami słuchania, dialogu, pocieszenia i wsparcia dla małżonków na ich wspólnej drodze i w ich misji wychowawczej. Niech rodziny zawsze znajdą w duszpasterzach wsparcie autentycznych ojców i przewodników duchowych, którzy będą je chronili przed zagrożeniami negatywnych ideologii i pomagali stawać się silnymi Bogiem i Jego miłością ${ }^{7}$.

Wyraźnie widać, jakie zadania stawia papież Franciszek duchownym, a co za tym idzie - pośrednio również osobom świeckim. Jak pisze także Jan Paweł II w adhortacji Familiaris consortio: „Kościół chce być bliski wszystkim małżeństwom, które napotykają na trudności” ${ }^{8}$. Kościół jednak to nie tylko instytucja, ale także wierni, którzy go tworzą, od tych najmniejszych struktur - Kościoła domowego i parafii.

Praca $z$ rodzinami w ramach duszpasterstwa rodzin realizuje się więc w kilku formach; szczególnie interesujące są parafialne

6 Por. Sobór Watykański II, Gaudium et spes, 52.

7 Franciszek, Audiencja dla polskich biskupów przybytych do Watykanu z wizytq „ad limina Apostolorum”, https://opoka.org.pl/biblioteka/W/WP/ franciszek_i/przemowienia/adliminapl_07022014.html (21.06.2019).

8 Jan Paweł II, Familiaris consortio, 33. 
poradnie rodzinne i poradnie specjalistyczne. Ich działania opisane są w dokumencie Konferencji Episkopatu Polski z 1 maja 2003 roku pod nazwą Dyrektorium Duszpasterstwa Rodzin 9 .

Parafialne poradnie rodzinne to miejsca organizowane przez proboszcza, gdzie posługują doradcy życia rodzinnego, czyli osoby, które skończyły studium życia rodzinnego i dostały misję kanoniczną. Doradcy podczas owego studium mają zajęcia, w których pojawia się zagadnienie mediacji, ale nie w wystarczającym dla jej prowadzenia zakresie. Inaczej może być w przypadku osób pracujących w poradni specjalistycznej, gdzie swoje dyżury mogą pełnić specjaliści z różnych wąskich dziedzin, w tym mediacji. Z założenia Dyrektorium Duszpasterstwa Rodzin wynika, że poradnie specjalistyczne powinny być w każdym rejonie czy dekanacie, tymczasem o tym, jakie to trudne, mogą świadczyć statystyki Instytutu Statystyki Kościoła Katolickiego. W przypadku archidiecezji krakowskiej w 2016 roku znajdowała się w jej obrębie tylko 1 poradnia specjalistyczna (podlegająca Wydziałowi Duszpasterstwa Rodzin); pracowali w niej: 1 duszpasterz, 7 specjalistów, 10 doradców. Liczba przyjętych klientów w 2016 roku wyniosła 500 osób. W archidiecezji krakowskiej znajduje się znacznie więcej poradni przyparafialnych - 83; pracuje w nich 158 doradców, natomiast nie odnotowano tam żadnych kapłanów i specjalistów ${ }^{10}$. Widać, że jest to przestrzeń do działalności, rozwoju i pozytywnej aktywności zarówno osób duchownych, jak i świeckich.

9 Por. Konferencja Episkopatu Polski, Dyrektorium Duszpasterstwa Rodzin, http://kodr.pl/wp-content/uploads/2017/03/dyrektorium_duszpasterstwa.pdf (21.06.2019).

10 Por. Instytut Statystyki Kościoła Katolickiego SAC, Katolickie poradnictwo rodzinne w Polsce w roku 2016, http://iskk.pl/badania/rodzina/267-poradnictwo-rodzinne-w-polsce (21.06.2019). 


\section{Mediacja w poradniach przyparafialnych i poradniach specjalistycznych}

W Piśmie Świętym znajdujemy przykłady polubownego rozwiązywania sporów opartego na zasadzie miłości bliźniego, szacunku do niego i uznania jego podmiotowości (por. 1 Kor 6, 1-9; Mt 18, 15-17), które można uznać za pośrednie promowanie mediacji. Papież Franciszek w swoim nauczaniu wyraża świadomość tego, że kryzysy w rodzinie są i będą, i one właśnie „są również częścią jej dramatycznego piękna. Trzeba pomóc odkryć, że przezwyciężony kryzys nie prowadzi do mniej intensywnej relacji, ale do udoskonalenia, konsolidacji i dojrzałości"11. Dlatego też mediacja zdaje się dobrą odpowiedzią na apel papieża o to, aby wspólnoty kościelne wspierały rodziny w przezwyciężaniu tych trudności, bo właśnie celami mediacji są m.in. odbudowa pozytywnych relacji, tworzenie postaw i zachowań pełnych akceptacji i szacunku, doprowadzenie do sytuacji przeprosin i wzajemnego przebaczenia stron.

Tutaj właśnie pojawia się podstawowe pytanie natury teoretycznej i praktycznej: czy mediacja rodzinna może być prowadzona $\mathrm{w}$ poradniach przyparafialnych i poradniach specjalistycznych? To pytanie rodzi kolejne, m.in.

- Czy cele mediacji wpisują się w zadania prowadzonego duszpasterstwa rodzin?

- Czy zachodzi niebezpieczeństwo dla zasady bezstronności i neutralności mediatora?

- Czy miejsce prowadzenia mediacji ma znaczenie dla stron?

- Czy mediator powinien podkreślać swój światopogląd w monologu mediatora lub w trakcie mediacji?

- Czy osoba duchowna może być mediatorem?

11 Franciszek, Amoris laetitia, 232. 
Celem tego artykułu nie jest udzielenie pełnej odpowiedzi na te pytania. Będzie jednak podjęta próba częściowego rozwiązania wskazanych trudności zgodnie ze zdobytą wiedzą praktyczną i teoretyczną. Jednocześnie należy pamiętać, że pełniejsza odpowiedź wymaga analiz badawczych i teoretycznych.

W pierwszej kolejności warto zastanowić się nad tym, czy mediacja wpisuje się w działalność duszpasterstwa rodzin: otóż zgodnie z tym, co przedstawiono powyżej, wydaje się, że tak. Mediacja we właściwy sposób współgra z zadaniami duszpasterstwa rodzin, a także wprost odnosi się do nauczania Kościoła o miłości i miłosierdziu do drugiego człowieka.

Drugie postawione pytanie dotyczy dwóch podstawowych zasad mediacji, czyli bezstronności mediatora i neutralności wobec przedmiotu sporu. Tutaj pojawia się, być może, największa trudność. Jeżeli sprawa, z którą przychodzą małżonkowie, dotyczy spraw okołorozwodowych, to czy mediator, który należy do Kościoła katolickiego i z założenia nie uznaje rozwodów, może starać się wpływać na strony, aby zrezygnowały z rozstania? Lub jeśli małżonkowie realizują niestandardowy podział ról w małżeństwie bądź w jakikolwiek sposób odbiegają od modelu preferowanego w nauczaniu Kościoła - czy mediator może starać się wywrzeć na to wpływ? W teorii oczywiste jest, że światopogląd mediatora nie powinien mieć absolutnie żadnego znaczenia w prowadzonej mediacji. Jednak czy w miejscu tak nacechowanym pewnymi wartościami jest możliwe, by zapewnił on pełną neutralność, a wobec stron pełną bezstronność? Czy też strony, które przyjdą do poradni przyparafialnej, a same są bardzo mocno związane $z$ wiarą i z religią, nie będą oczekiwać od mediatora pewnego ustosunkowania się do tego? Tutaj pojawia się pytanie trzecie: czy miejsce ma znaczenie dla stron? Czy w dzisiejszym świecie, gdy więcej relacji się wymienia na nowe, zamiast je naprawiać, Kościół daje gwarancję, że w jego strukturach będzie podjęta walka o to małżeństwo? 
Czy strony, które chcą, by ktoś pomógł im walczyć, idą właśnie do miejsca, w którym uznaje się, że rozwód nie jest jedynym wyjściem? Ale wobec tego czy mediator powinien przedstawiać swój światopogląd i swoją wiarę w monologu? Zgodnie z założeniem mediacji w ogóle nie powinien on podejmować innych tematów niż te, których wymaga monolog. Poza tym wydaje się, że podkreślanie $\mathrm{w}$ monologu, z jakim charakterem poradni ma się do czynienia, nie jest konieczne, bo zwykle sale, w których odbywają się takie spotkania, wyraźnie wskazują na specyfikę tego miejsca. Wobec tego czy osoba duchowna może być mediatorem? W porządku prawnym - oczywiście, że może, jeżeli posiada odpowiednie przeszkolenie, kompetencje, jeśli ma powyżej 26 lat, pełną zdolność do czynności prawnych, nie ma ograniczonych praw publicznych i nie jest skazana za umyślne przestępstwo ${ }^{12}$. Jeśli natomiast padnie pytanie, czy osoba duchowna powinna być mediatorem, pojawi się pewna trudność. Większe niebezpieczeństwo braku bezstronności może wystąpić właśnie w przypadku osoby duchownej niż osoby świeckiej. Ale w rzeczywistości wszystko rozbija się o profesjonalizm mediatora. Warto jednak zaznaczyć, że narzędzia i sposoby pracy mediatorów mogą znaleźć swoje zastosowanie w pracy z drugim człowiekiem również poza samą mediacją. Osoba duchowna może więc korzystać $z$ metod pracy mediatora, ale nie $z$ samej formy mediacji.

$\mathrm{Na}$ koniec tych rozważań warto się zastanowić nad samym miejscem mediacji w poradniach przyparafialnych. Czy spotkania $\mathrm{z}$ mediatorem oferowane $\mathrm{w}$ poradniach są spotkaniami stricte poradniczymi, podczas których mediator tłumaczy, czym jest mediacja, jakie są jej przebieg, zasady i skutki? Czy prowadzi mediację zgodnie z procedurą, czyli spotyka się z parą kilkakrotnie,

12 Por. Rozporządzenie Ministra Sprawiedliwości z dnia 20 stycznia 2016 r. w sprawie prowadzenia listy stałych mediatorów (Dz.U. z 2016 r. poz. 122). 
dochodzą razem do porozumienia i spisuje je? Jeśli prowadzi spotkania o charakterze porady, to pojawia się pytanie, czy ma ku temu odpowiednie wykształcenie (czy uczestniczył w kursach lub szkoleniach, a może w studium życia rodzinnego były zajęcia poświęcone temu zagadnieniu?). Jeśli prowadzi mediację rodzinną, to powstaje pytanie, czy przynależy do jakiegoś stowarzyszenia mediatorów, czy jest wpisany na listę mediatorów przy sądzie okręgowym. Mimo że mediacje cywilne, w tym także rodzinne, nie mają takich obwarowań prawnych, gdy idzie o wymogi formalne wobec osoby mediatora, jest to ważne w kontekście poziomu prowadzonych mediacji i ich wiarygodności. Co więcej, jeśli przyjrzymy się innym specjalistom pracującym w poradniach specjalistycznych, takim jak lekarze psychiatrzy czy psychoterapeuci, to oni w swojej pracy w poradni nie prowadzą długoterminowej terapii ani nie wypisują recept. Wobec tego czy mediator powinien prowadzić mediację? Ta procedura jest z założenia dość krótka, bo ma trwać około czterech-pięciu spotkań, i jeśli jest mediacją pozasądową lub jeśli strony nie oczekują klauzuli wykonalności, to nie musi w ogóle być nigdzie rejestrowana. Wobec tego czy mediacja „nieformalna”, ale mająca zgodny ze sztuką proces, może być prowadzona przy parafii?

Analizując przedmiot mediacji w poradniach przyparafialnych bądź poradniach specjalistycznych, warto zdawać sobie sprawę także z tego, że zdarza się, iż strony przychodzą ze sprawami, które $\mathrm{z}$ założenia nie podlegają mediacji, tylko terapii małżeńskiej; czasem mogą się zdarzyć sytuacje w rodzaju np. przemocy domowej, w której mediacja nie powinna mieć miejsca ze względu na nierównowagę stron. Należy także mieć na uwadze, że można zaobserwować różne postawy stron, np. obie strony chcą dojść do porozumienia i naprawić relacje,jedna ze stron chce pokonać drugą i uzyskać dla siebie jak najwięcej korzyści, może także chodzić o wołanie o pomoc czy chęć zwrócenia na siebie uwagi. $\mathrm{Na}$ te 
wszystkie potrzeby może odpowiedzieć doradca życia rodzinnego, psycholog czy mediator właśnie, przy czym należy odróżnić spotkania o charakterze porady dotyczącej mediacji i rozwiązywania sporów od spotkań mających na celu przeprowadzenie mediacji.

Podsumowując, niezależnie od tego, z jakim rodzajem pracy z mediacją mamy do czynienia w przypadku spraw małżeńskich, należy pamiętać o kilku podstawowych kwestiach, które można streścić w poniższych punktach:

- mediator w żaden sposób nie może nakłaniać stron do zaniechania rozwodu;

- mediator w żaden sposób nie może nakazywać życia religijnego, brania udziału w sakramentach czy ewangelizować w inny sposób;

- mediator w żaden sposób nie może wydawać osądów, oceniać stron czy wywyższać jedną ze stron.

Natomiast w przypadku spotkań o charakterze doradczym czy poradniczym:

- może mówić o wartości pojednania, miłosierdzia w życiu rodzinnym i małżeńskim;

- może informować o przebiegu mediacji, o rodzajach mediacji, przedmiotach mediacji, o tym, gdzie jest prowadzona itd.;

- może pokazywać stronom, na czym mniej więcej polega mediacja, np. udrożnić komunikację i przedstawić, jak inaczej może ona wyglądać.

Powyższe punkty mogą służyć jako podsumowanie i punkt wyjścia do dalszych analiz tego problemu, który powinien $z$ biegiem czasu się rozwijać i pozytywnie wpływać na rozwój zarówno duszpasterstwa rodzin, jak i samego popularyzowania mediacji jako takiej.

Analizę teoretyczną i praktyczną z pewnością można rozpocząć od zapoznania się np. z zagadnieniem mediacji chrześcijańskiej, o której można przeczytać na stronie Your Family Mediator czy 
Resolve Christian Mediaton ${ }^{13}$. W obrębie tego drugiego ośrodka prowadzone są mediacja, arbitraż, a także szkolenia $z$ dziedziny alternatywnych metod rozwiązywania konfliktów - o charakterze chrześcijańskim i na podstawie chrześcijańskiej nauki. Pojawiają się także artykuły zbliżone tematycznie ${ }^{14}$ do niniejszej pracy. Mimo to nadal nie jest to ściśle naukowe opracowanie na temat mediacji rodzinnej w poradniach przyparafialnych.

Artykuł ten miał na celu wskazać na trudności etyczne, praktyczne i organizacyjne mediacji w działalności poradni przyparafialnych i poradni specjalistycznych. Wydaje się, że jest to temat niedostatecznie omówiony, nieuporządkowany, a jednocześnie bardzo potrzebny dziś i prawdopodobnie jeszcze bardziej potrzebny w przyszłości.

\section{Wybrana bibliografia}

1. Brzeziński M., Duszpasterskie wsparcie rodziny, w: Wsparcie rodziny. Zatożenia i praktyka w ujęciu interdyscyplinarnym, red. A. Regulska, A. J. Najda, Warszawa 2017, s. 75-95.

2. CRG Crossroads, http://www.crossroadsresolution.com/ churches-and-ministries (5.09.2019).

3. Cybulko A., Mediacja w sprawach rodzinnych, w: Mediacje. Teoria i praktyka, red. E. Gmurzyńska, R. Morek, Warszawa 2014, s. 299-318.

4. Franciszek, Amoris laetitia, Wrocław 2016.

13 Por. Your Family Mediator, http://www.yourfamilymediator.com/ (5.09.2019); Resolve Christian Mediaton, https://resolvechristianmediation.com (5.09.2019).

14 Por. C. Patterson, Conflict Resolution for Churches?, https://www.bbministries.org.uk/article/conflict-resolution-for-churches/ (5.09.2019); CRG Crossroads, http://www.crossroadsresolution.com/churches-and-ministries (5.09.2019). 
5. Franciszek, Audiencja dla polskich biskupów przybytych do Watykanu z wizytq „ad limina Apostolorum”, https://opoka.org. pl/biblioteka/W/WP/franciszek_i/przemowienia/adliminapl_07022014.html (21.06.2019).

6. Instytut Statystyki Kościoła Katolickiego SAC, Katolickie poradnictwo rodzinne w Polsce w roku 2016, http://iskk.pl/badania/ rodzina/267-poradnictwo-rodzinne-w-polsce (21.06.2019).

7. Jan Paweł II, Familiaris consortio, Wrocław 2000.

8. Kalisz A., Zienkiewicz A., Mediacja sqdowa i pozasądowa. Zarys wyktadu, Warszawa 2014.

9. Konferencja Episkopatu Polski, Dyrektorium Duszpasterstwa Rodzin, http://kodr.p1/wp-content/uploads/2017/03/dyrektorium_duszpasterstwa.pdf (21.06.2019).

10. Patterson C., Conflict Resolution for Churches?, https://www. bbministries.org.uk/article/conflict-resolution-for-churches/ (5.09.2019).

11. Przygoda W., Dowartościowanie mitości i mitosierdzia w duszpasterstwie rodzin, w: Towarzyszyć matżenstwu i rodzinie. Inspiracje adhortacji apostolskiej „Amoris laetitia” dla duszpasterstwa rodzin, red. J. Goleń, Lublin 2017, s. 149-162.

12. Resolve Christian Mediaton, https://resolvechristianmediation. com (5.09.2019).

13. Rozporządzenie Ministra Sprawiedliwości z dnia 20 stycznia 2016 r.w sprawie prowadzenia listy stałych mediatorów (Dz.U. z 2016 r. poz. 122).

14. Sobczak E., Mediacja rodzinna jako forma polubownego rozwiqzywania sporu, w: Rodzina. Podstawy prawno-teologiczne, red. J. Zimny, Stalowa Wola 2015, s. 663-672.

15. Sobór Watykański II, Konstytucja duszpasterska o Kościele w świecie współczesnym Gaudium et spes, Wrocław 2005.

16. Your Family Mediator, http://www.yourfamilymediator.com/ (5.09.2019). 